International Journal of Engineering \& Technology, $7(3.21)(2018) 161-170$
International Journal of Engineering \& Technology
SPC
Website: $\frac{\text { www.sciencepubco.com/index.php/IJET }}{\text { Research paper }}$

\title{
An Analysis of the Relationship between Risk and Expected Return in Malaysia Stock Market: Test of the CAPM
}

\author{
Koh Xin Rui ${ }^{1}$, Devinaga Rasiah ${ }^{2}$, Yuen Yee Yen ${ }^{3}$, Suganthi Ramasamy ${ }^{4}$, Shalini Devi Pillay ${ }^{5}$ \\ ${ }^{1,2,3,4,5}$ Faculty of Business, Multimedia University, Jalan Ayer Keroh Lama, 75450 Melaka, Malaysia. \\ *Corresponding author E-mail: devinaga.rasiah@mmu.edu.my
}

\begin{abstract}
Investment theory describes the concept of relationship between risk and return. Capital Model Asset Pricing Model (CAPM) was based on the risk and return relationship. CAPM described that asset's expected return that is above the risk free rate is directly related to the non-diversifiable risk that is measure by beta. Focus of this study is to identify the impacts of risk toward the stock return in Malaysia stock market during the year 2007 to 2015 by testing on the applicability of Capital Asset Pricing Model. The data is from monthly stock returns from 24 companies listed on the stock exchange for investigation. The analysis of monthly stock market closing indexes from using regression model was carried out on the standard CAPM model. When testing the CAPM model for the whole period, it has not showed strong evidence that support the validity of this model and in order to get better estimates, this study divided the whole sample into 3 sub periods of five years each. The study found high beta value does not related to higher level in stock return. The positive relationship between systematic risk and return does not have a strong evidence to support it. The research also identify that the securities market line has direct relationship between risk and return. The unsystematic risk does not have an effect on the return. It means that stock prices cannot be effectively predicted by CAPM and Malaysia Stock and the validity of CAPM does not exist in Malaysia Stock Exchange Market for the period 2007-2015 due to some limitations such as time frame, sample size and others. This paper suggest a different assets pricing model and takes into consideration of some related variables in predicting future stocks returns. This research provides important implication to investors, analysts, stock brokers, speculators, fund managers, practitioners, relevant authorities, and government.
\end{abstract}

Keywords: Risk; Return, CAPM; Beta ( $\beta)$; Systematic Risk; Unsystematic Risk

\section{Introduction}

Stock market has a prominent role in assisting and stimulating the development of economy of a country. Stock market is utilised to implement the privatisation programs, where it has indispensable role in the growth of emerging economies. In order to enhance efficiency and effectiveness of a country's economy, stock market always has the ability to channel funds and financial instruments from firms or people who do not have any investment chances into a firms or individuals that have the opportunity to invest. Stock market also provides a wide range of unique and attractive investment opportunities for investors to involve themselves into investment. Growth of Malaysia stock market has prompted an assess on the risk inherent in the market by economic agents (both domestic and internal) (1). Financial risks are relatively a recent inconvertible fact that needs to be concerned in the stock market. Risk is defined as the possibility to lose partially or even whole original investment by taking into account that expected return will be different from actual return. Most literature expresses the term of - riskll as covering two elements. Firstly, it is the possibility of negative event to be happened during the lifetime; secondly, it is meant the resultant effect when a negative event has occurred $(2,3)$. Investors can make better decision in investing the assets or securities by evaluating the relationship between expected return and the risk on security accurately.
There are a plenty of models that display trade-off between the relationship of risks and return. One of them is Capital Asset Pricing Model (CAPM). Systematic risk is only the risk that is being considered by CAPM. Market risk is considered as the most significant risk factors among the systematic risk. Individual asset prices like stock prices are also being indicated by plenty researches as they are not sensitive to market risk only. The asset price are also affected to other systematic risks such as economic news (4). Stock returns are also being affected by unexpected volatile in macroeconomic variables such as inflation or fluctuation in exchange rate.

\subsection{Problem Statement}

CAPM has been condemned for some unrealistic assumptions and this criticism has made many further theoretical works on CAPM to refine the model by including some other variables into the model. Despite being criticized, CAPM still a vital component of the financial market through its role in the valuation of certain investment such as evaluation (5). The CAPM is used to analyse connection concerning risk and expected return that it is used in pricing of the risky stocks. The CAPM states that - expected return on a security is equal to the rate on a risk-free security plus a risk premium (6)\|. Therefore, the CAPM model independently implies and establishes a positive linear relationship between beta risk of the stocks and expected return. This means that securities with higher beta need to have more expected return compare to the securities with lower beta. Therefore, this study is mainly devoted 
to analyse risks facing by Malaysia stock market by using CAPM and analyse the correlation and the inter-dependency

The financial institution that plays an important role in Malaysia is the Bursa Malaysia Stock Exchange, which is formerly recognised as Kuala Lumpur Stock Exchange (KLSE). KLSE is approved under Section 15 of the Capital Markets and Services Act 2007 and it is an exchange holding company. It functions a fully integrated exchange, provides comprehensive range of exchangerelated services, depository services and trading infrastructure for companies, investors and other related parties. KLSE positions itself as centre of Malaysia's capital market. Kuala Lumpur Stock Exchange is a key player in driving Malaysia's economy. There is also investment alternative offering for retail and institutional investors, both domestically and overseas, integrated products and services.

Due to securities investment, investors often will experience conflict between securities and rate of return. According to high rate of return, investors would have to agree with high-risk when the risk is that investors cannot avoid. Investors only will hold a risky asset if they are compensated with commensurably higher returns, therefore expected return on assets need to increase as risk and uncertainty increase. However, there is confusion in people's mind that is really a high risk of portfolio gain a high return on investment? Sometimes, there are high (low) beta companies with low (high) returns which are clear deviations from the predictions of the CAPM.

Recently, many researches have explored on risk and return's concept and theory by testing on different financial markets. However, the results portray are differing from one to another. The validity of the CAPM has been extensively tested in developed markets. Due to most of the studies have been done are in the developed countries financial market, and for the emerging countries'financial market, there are only few take into account for emerging countries such as Malaysia market. Malaysia is still being recognised as an emerging country and Malaysia is not considered as a developed country (United Nation, 2014) Therefore, there is confusion that whether the result generated from CAPM for the risk and return relationship will be the same in the emerging country as compare to the developed country.

Therefore, this research is study about risk and return analysis in Malaysia stock market by using CAPM.

\subsection{Research Objectives}

Broadly speaking, this research tends to look into the relationship between risk and return in the Malaysia Stock Market. It is critical to apprehend the relationship because these aspects will influence the decision making of investors.

The objectives of the study are:-

1. To examine whether a lower/higher risk stocks yields lower/higher expected rate of return.

2. To investigate whether the expected rate of return and stock beta/systematic risk is linearly related.

3. To analyse the relationship between unsystematic risk and expected return.

4. To examine the validity of Capital Asset Pricing Model in Malaysia Stock Market.

This research is basically studying on risk and expected return relationship in Malaysia stock market. This study tends to look into whether the high risk is necessary guaranteed by the high return. Generally, high risk will be compensated by a high return. However, there is no guarantee that anyone who invests their money in a more risky stock and accept more risk will actually get a higher return.

This study focuses on part of the chronicle by establishing the direction of interdependence between risk and return in Malaysia Stock Exchange with optimism that our empirical findings could give some insights to the companies in solidifying and making a sound financial market. Risk is considered as one of the most critical variables in Malaysia economy. A changing in risk of stock will lead to a changing in return. Changing in the return will impact theoretical value of a company and its share. If the returns increase, the share value should rise. Stockholders will increase their share price and return. Therefore, it is necessary for stockholder to have a look into relationship between risk and return. This research inspects the CAPM and examines its non- diversifiable risk measured by its beta.

The methodology that is used for this sample is secondary data. Data used in this study for Malaysia stock market called KLSE (Kuala Lumpur Stock Exchange) and monthly stock returns are used from 30 companies which are listed on the Malaysia stock exchange for the period January 2007 to December 2015. However, after screening through all the criteria, there are only 24 firms are selected to form the portfolio for this research.

\section{Literature Review}

\subsection{Capital Asset Pricing Model (CAPM)}

In the finance area, CAPM is a herald as the beginning of asset pricing theory (7). Few decades later, CAPM is still being commonly used for assessing the performance of various managed portfolios and approximating cost of capital for different investment companies. In order to realise relationship between risk and return, CAPM is a powerful model in this area. CAPM is an extension of Modern Portfolio Theory (MPT). For MPT, variance analysis concentrates on how investors need to allocate their wealth by investing in various assets or stocks that are available in the market. CAPM depicts that the risky assets 'equilibrium rates of return are a function of their covariance with market portfolio. According to CAPM, there is a linear relationship exists between and risks associate with the investment and return on investment. This model examines the security market line and as well as systematic risks (beta coefficient) and expected return relationship. This model also acts as a key element of how markets can value their individual securities 'return along with different risk levels (8). Calculation of return-to-risk ratio for securities is enabled by security market line in the overall market. Return-to-risk ratio for the individual security will become equivalent to market return-torisk ratio when expected rate of return gets deflated by the beta coefficient.

\subsection{Arbitrage Pricing Model (APT)}

In 1976, a new symmetry asset pricing model was developed by Stephen Ross. Arbitrage arguments was based to derive this model and thus it is called the arbitrage pricing theory model. APT is another equilibrium pricing model used to examine risk-return relationship. APT provides a testable alternative for CAPM. APT substitutes CAPM's assumption which is according to the mean variance framework by the assumption of procedure that generating returns on security. APT model assumes there is a direct relationship to the risky assets 'return and mixture of various common factors that will affect the assets 'returns.

According to factor model of asset's return, APT assists in comprehending of equilibrium pricing relationship (9). In order to comprehend and investigate the expected return's equilibrium for financial instrument, APT is considered as one of paradigms or alternative ways that can be used .The theory has the premise that for any financial market that considered to be as the arbitrage-free is the market that is very healthy, well-functioning and robust (10) APT is concerned to be a one-price model. It implies that each single financial specialist in market has the belief that asset's returns of stochastic properties are accordance with a specific factor structures (11). The estimated returns on assets can be reckoned have a linear manner related to the betas or factor loadings if the equilibrium price does not provide any opportunity of Arbitrage over effective portfolio. Returns and betas or factor loadings have 
a linear relationship between each other and that situation can be known as - stochastic discount factorl (12).

Comparing CAPM and APT First and foremost, the difference is regarding to their factor model. CAPM has its source in singlefactor model (13), which explains that investors need to be compensated for two main things which are time value and risk. On other hand, Arbitrage Pricing Model is a multi-index. It implies a combination of numerous various factors that usually omit market portfolio is returns-generating method. Those factors are not decide in advance and the choice is made depend on the issue in hand (14).

The second differentiating factor which is related to the CAPM and APT model is notion of the equilibrium. Assumption of efficient market portfolio is worked by CAPM, while Arbitrage Pricing Model relies hugely on market of the nonappearance of free arbitrage (10).

It is can be clearly seen that APT model is an improved version of the CAPM. However, CAPM is more simple-minded model as compare to APT. CAPM can estimate beta more exactly, so required return is accurate rationally. Theoretically APT model may be more progressive, but this is offset by the magnificent estimation error. Since CAPM is simpler to comprehend and at ease to use, that is why CAPM is used in this research.

\subsection{Dependent Variable - Expected Return}

Recently, the return from the portfolio of the stock has been become one of the top most growing concerns for investors, governments, organisations and the international community alike. Two lessons can be learnt from the capital market history: - the riskier the assets, on average, gain a risk premium, as well as the higher the potential reward, the higher the risk (15). Risk and return is always highly correlated among each other as investors always assume that risk of investment will compensate with equal amount of return. Return is referred to - the summation of investment income and any changes in market price (which is expressed by investment beginning market price percentage) (16).

\subsection{Independent Variable Risk}

Any coincidental that some unfavourable incident will happen such as danger, jeopardy, and exposure to damage or injury is referring to risk (17). Most of the people are taking a risk in hoping to have an appreciable return when they are investing in any risky asset. Risk also is a combination of danger, and opportunity. Due to company-unique risk can be diversified away; it also can be called as diversifiable risk. Result factors that are specific to each particular firm, company or industry are known as diversifiable risk According to (18), it also mentioned that the market risk still survive even after extensive diversification. Market risk also name as systematic risk or non-diversifiable risk and unique risk that can be eliminated away by diversified away by portfolio is called firm specific risk, unique risk, diversifiable risk, or nonsystematic risk.

\subsection{Interest Rate Risk}

"Interest rate risk can be described as possibility that the interest rate earned on investments may lower than the rise of market interest rate, resulting in their lower market value. Interest rate risk also can be defined when there is an alteration in interest rate, as probability of fall in bank's profitability (19). Interest rate risk can be concluded as present and forthcoming risk to earnings or capital arising from fluctuation in interest rates. There were many studies had concentrated on examining the interest rates risk effect on the financial stock returns $(20,21)$. The investigation of interest rate risk was started by putting in the interest rate into the measurement by returns from debt market that was used to estimate the market risk. It was counted as an evolution of a two-index model as an extension of the single-index market model (22). His explo- ration demonstrated that financial institutions' stock returns showed a significant sensitivity to interest rate risks.

\subsection{Inflation Risk}

Inflation rate is characterised to be percentage variation in general price level of the economy. Relationship amongst inflation and stock returns is initially originated in Fisher effect's context which is also called Fisher hypothesis. (23) classified Fisher effect as one of the economic theories and it is used to clarify the relationship between inflation and return (23). Fisher effect theory implies that nominal return of stocks will change when inflation rate fluctuate. When inflation rate increases, stock returns will increase; when the inflation rate decreases, the stock return will decrease. Fisher theory was a justification for relationship between stock and inflation for most of period from 1930 to 1970 only. During the period 1970, majority investors discovered there was a negatively related between inflation and stock return. This implied Fisher theory wavered in short and intermediate terms (24).

\subsection{Exchange Rate Risk}

Exposure is known as relation or sensitivity of varies in value of asset or liability results in a fluctuation in exchange rate (25). Modelling exchange rate exposure has been a vital developing and growing area of research in most recent decade. Based on (26), the study indicated the firm's systematic risk was affected by the fluctuation of exchange rates and market value. There was a study showed causal relationship between exchange rates and stock prices were significant.

\subsection{Unsystematic Risk/Specific Risk}

Unsystematic risk is a risk that apply only small group of stocks or a single stock. Unsystematic risk can be eliminated away by a well diversification through portfolio. Combining various stocks from various industries, unsystematic risk of securities can be diversifying away and accuracy of beta estimation can be enhanced (27). (28) studied considered systematic and unsystematic risks (including the leverage effect) simultaneously. According to Yingyan Guo (29), unsystematic risk does not affect the stock return in Shanghai Stock Exchange during the period 2005 to 2009. (30) also stated that unsystematic risk showed insignificant for Dhaka stock exchange. The residual risk had not influence on the stocks' expected return also being proved by (31).

\subsection{Risk and Return Relationship}

Investors always choose the stocks they want according their risk appetite when investing in any stocks. Logically, high return is accomplished by high risk. Investors that prefer to be compensated with higher return will select the stocks with large beta and they are high risk appetite. In contrary, investors who do not want to take so high risk will choose low beta stock and associate with safe and low return. They are low risk appetite.

Few studied had investigated beta-return relationship. (32) summarised that between 1963 and 1990, (33) inspects beta-return relationship and a result of there was no any relationship between two variables was portrayed. However, this result had been argued on three fronts (32). First and foremost, (34) maintained the identical data by performing in dissimilar statistical tests, the result indicated betas changed actually can affect changed in returns. Secondly, (35) used the annual data instead of shorter intervals in numerous tests to estimate betas and came out a result by saying beta actually can describe a significant proportion of variances in returns. Thirdly, (36) indicated in the period after 1982, betareturn positive relationship was broken down only by looking from 1926 to 1991 at a much lengthier time series of returns. They portrayed that beta was suitable guideline to risk during thrilling market conditions. 


\section{Development of Theoretical Framework and Hypotheses}

Based on the theoretical framework in Figure 3.1, hypotheses will be made based on the dependent variables and independent variables. The hypothesis will be tested in this research in order to investigate the relationship between risk and return.

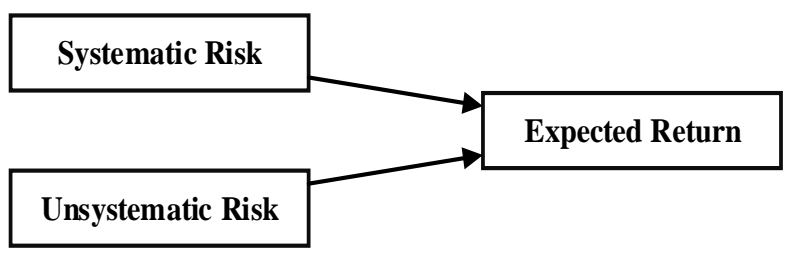

Fig. 1: Theoretical Framework

\subsection{Expected Return (Dependent Variable)}

Expected return is the dependent variable in this research. From the above literature review, risk and return always have a significant positive relationship between each other(37, 38). Market risk is the most critical factors in affecting the return among other various systematic risks that will affect the stock return. Several researches have shown that the profits and returns are correlated with the unsystematic risk $(39,40)$.

\subsection{Systematic Risk/ Beta (Independent Variable)}

Hypothesis statement 1

$\mathrm{H}_{0}$ : There is no significant positive relationship between betas and expected stock return in Malaysia stock market.

$\gamma_{1}=0$

$\mathrm{H}_{1}$ : There is a positive and statistically significant relationship between risk and expected stock return in Malaysia stock market $\gamma_{1}>0$

The rejection of null hypothesis may view as a support for Capital Asset Pricing Model.

The systematic risk touches upon on the risk that cannot be diversified away through the portfolio. The result indicates there is a positive and significant relationship between return and the systematic risk. Existence of risks in the market has been proved by many previous studies and a positive relationship between these risks and return of the market has been detected $(41,42)$ However, some studies indicate that risk and return relationship is not always positive at any time. (43) discovered that although there was always a positive relationship was shown during the up market, but there was a negative relationship between risk and return was indicated during down market.

Hypothesis statement 2

$\mathrm{H}_{0}$ : Expected rate of return is linearly associated to stock beta. $\gamma_{2}=0$

$\mathrm{H}_{1}$ : There are no non linearity between stock beta and expected rate of return.

$\gamma_{2} \neq 0$

The rejection of alternative hypothesis may be viewed as a support for Capital Asset Pricing Model.

Many studies prove an empirical result of there is a significant positively linkage between realised return and systematic risk as measured by beta, and there is linear relationship arise between risk and return(44-46). (47) and (48) also proved that there was a linear relationship between beta and return in Istanbul stock exchange. Expected return-beta relationship is linear also was being proven in the Amman Stock Exchange (49)In Australian Industrial equity market, cross sectional relationship between beta and average return is also in a situation of linear(50).

\subsection{Unsystematic Risk (Independent Variable)}

Hypothesis statement 3

$\mathrm{H}_{0}$ : The unsystematic risk has no effect on stock's returns at Malaysia Stock Market.

$\gamma_{3}=0$

$\mathrm{H}_{1}$ : The unsystematic risk has effect on stock's returns at Malaysia Stock Market.

$\gamma_{3} \neq 0$

Failure to reject null hypothesis may be viewed as evidence in support of Capital Asset Pricing Model.

The unsystematic risk refers to the risk that can be diversified away through a well portfolio, such as company specific risk. According to Yingyan Guo (29), unsystematic risk does not affect the stock return.(30) also stated that unsystematic risk showed insignificant for Dhaka stock exchange. The residual risk had not influence on the stocks' expected return also being proved by (31). There were also some several researches had shown that the profits and returns were correlated with the unsystematic risk $(39,40)$.

\subsection{Statistical Analysis}

Non-parametric model linear progression technique is being used to test for this study. Parametric model is not suitable to be used in this study due to the reason that the sample collected is small and the require information is incomplete and limited for the study. The method used will accord to a statistical assessment of risk in financial area.

Fama and MacBeth's Capital Asset Pricing Model is being used to test the risk and return relationship in this research. This model can be to determine the significance of market risk on the companies' expected return. CAPM acts as an economic theory has explained the risk and return relationship and asserts that systematic risk is only the risk that is being priced by the rational investors because it is the risk that cannot be diversified.

Security Market Line (SML) equation uses to test the risk and expected returns relationship. In CAPM, beta can also be used to examine the systematic risk.

The CAPM asserts that:

$$
\mathbf{R}_{\mathrm{i}}=\mathbf{R}_{\mathrm{f}}+\left(\mathbf{R}_{\mathrm{m}}-\mathbf{R}_{\mathrm{F}}\right) \boldsymbol{\beta}
$$

Where;

$R_{\mathrm{i}}$ : expected retum on the capital asset $\mathrm{i}$;

$\mathrm{R}_{\mathrm{f}}$. risk-free rate of interest;

B: security beta

$\mathrm{R}_{\mathrm{m}}-\mathrm{R}_{\mathrm{F}}$ :market risk premium

\subsection{Data Description}

During the period of year 2007 to 2015, 24 companies which are listed in the Malaysia Stock Exchange's monthly share prices are being collected to be used in this research. The shares that are chosen as a sample in this research need to meet the criteria that there are listed in the stock exchange continuously during the period. In a specific year, the shares prices also need to be available in every month. Dividend of stocks and cash are not revised for the end of monthly share because of the inaccessibility of data will result in underestimation of stock returns.

Computation of stock price returns:

$$
R_{i f}=\operatorname{In}\left(\frac{\text { Pit }}{\text { Pi,t-1 }}\right)
$$

\section{Where}

$\mathrm{R}_{\mathrm{it}}=$ Stock $i$ 's return.

$\mathrm{P}_{\mathrm{it}}=$ Stock $i$ 's price per share at the end of the month $t$.

$\mathrm{P}_{\mathrm{i}, \mathrm{t}-\mathrm{l}}=$ Stock $i$ 's price per share at the end of the month $t-1$. 
Formula of the monthly stock market returns $\mathrm{R}_{\mathrm{m}}$ :

$$
R_{m}=\operatorname{In}\left(\frac{P m t}{P m, t-1}\right)
$$

Where

$\mathrm{R}_{\mathrm{mt}}=$ market's monthly return.

$P_{m t}=$ Value of Kuala Lumpur Composite price index at the end of the month $t$.

$\mathrm{P}_{\mathrm{m}, \mathrm{t}-\mathrm{l}}=$ Value of Kuala Lumpur Composite price index at the end of the month $t-1$.

$\ln ()=.\log$ arithm operator.

Dividends are not adjusted in this research and local currencies are being used as a measure currency for the returns. January 2007 to December 2015 is being examined as analyse period for this study. The data observations obtained were 60 months(51).

The time period is being reallocated into three 5 -year sub-periods just like (52) to smooth out the possible volatility of beta coefficients through overlapping year in each consecutive period as recommended by (53). Each sub period is divided into 5 year because of the five year rule of thumb(54)

The testing period is being used as beta estimation periods.

The periods of the study are as follow:

1. Whole period: 2007.1.1 - 2015.12.31.

2. First sub period: 2007.1.1 - 2011.12.31;

3. Second sub period: $2009.1 .1-2013.12 .31$;

4. Third sub period: 2011.1.1 - 2015.2.31;

As this research has a small sample, only a portfolio will be used rather than separating the sample into many portfolios. Therefore, individual stock betas will be used in this research. Portfolio beta can be ignored in this research since the individual stock beta is already used in this study.

This research will monitor Black, Jensen and Scholes method to prevent the measurement bias of beta. The beta of last period is used for valuing beta and theses are focused in grouping of following period. Then, this approach can be used to reduce statistical errors from beta estimation.

Time series specification as well as Cross sectional specification of Capitl Asset Pricing Model will be conducted in this research to examine the relationship between risk and return.

\subsubsection{Time Series Regression}

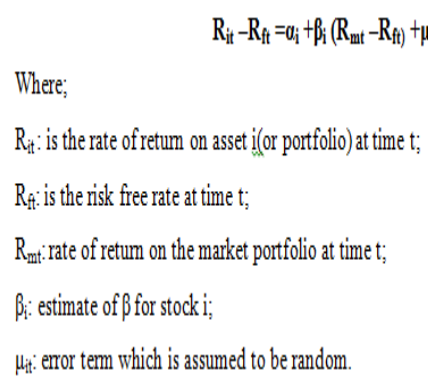

For the first phrase, time series specification is being constructed as follow:

In first phase of analysis, time series specification is being conducted to examine the regression relationship between market return and stock returns. Time series specification is used to investigate their specific beta coefficient for each sub -period as well as for the whole period of year 2007 to 2015 . It also regress the dependent variable which is excess return on the independent variable which is market premium. Beta coefficients of individual shares are considered as the output of regression for each period under investigation.

Coefficient $\alpha \mathrm{i}$ is determined by the difference between time series average's estimated expected return and expected return as specified by CAPM. As CAPM asserts that, regression intercepts value for assets or portfolio will be equal to zero if there is an expected return and a correct market portfolio is being chosen.

\subsubsection{The Cross-Sectional Regression}

For second phase, Cross-sectional specification of CAPM is used to examine the risk- return relationship for this research. The following regression model is being conducted base on Fama and Macbeth cross-sectional regression of excess return of the stocks in portfolio $\mathrm{A}$ on the estimated betas for each sub- period:

$R_{\text {it }}-R_{\mathrm{f}}=\gamma_{0 \mathrm{t}}+\gamma_{1 \mathrm{t}}+\beta_{\mathrm{it}}+\mu_{\mathrm{it}}$

When $\gamma_{0 \mathrm{t}}=0$ and $\gamma_{1 \mathrm{t}} \neq 0$, and CAPM's validity is being proved.

Some specific tests are being run to verify all the assumption around the CAPM test hold true. The below equation is being used to examine the nonlinearity relationship between total stock return as well as the betas.

ri $=\gamma_{0}+\gamma_{1} \beta_{i}+\gamma_{2} \beta^{2}{ }_{i}+e_{i}$

SML signifies a linear relationship between expected return and risk if the CAPM hypothesis holds $\gamma_{2}$ equivalent to zero. After that a measurement by the residual variance is being constructed to investigate whether the securities' expected excess return are related to one systematic risk only and it is independent from the non-systematic risk. The following equation is being set for this model:

$$
\text { ri }=\eta_{0}+\eta_{1} p_{i}+\eta_{2} p_{i}^{2}+\eta_{3} \delta^{2}\left(e_{i}\right)+e_{i}
$$

\section{Where}

\section{$\eta_{2}$ is the measure of the potential nonlinearity of the return,}

\section{$\gamma_{3}$ estimates the explanatory power of non-systematic risk}

\section{$\delta^{2}\left(\mathrm{e}_{\mathrm{i}}\right)$ measures the residual variance o portfolio or stocks returm}

$\gamma 3$ should be equivalent to zero and the unique risk that can be diversified away should not influence the return if CAPM hypothesis is true (55).

Therefore, after conducting the regression, there are 4 estimates of the coefficients will be revealed up and hypotheses can be tested based on the following criteria(56):

i. $\gamma_{0}=0$, should not be significantly different from zero;

ii. $\gamma_{1}>0$, positive price of risk presents in the market;

iii. $\gamma_{2}=0$, linearly related between risk and return;

iv. $\gamma_{3}=0$, unsystematic risk has no effect on the expected return.

T-test will be used in this research in order to statistically investigate CAPM.

\section{Findings}

\subsection{Regression Result from Time Series Data}

As earlier mentioned a time series regression of the monthly stocks' returns is running over the monthly market index returns to estimate the beta for each stock.

Monthly returns on each stock are calculated as explained in above chapter for the nine years period and each sub periods. Therefore, we have the following overall results. From the equation of $\mathrm{R}_{\mathrm{it}}-\mathrm{R}_{\mathrm{if}}=\alpha_{\mathrm{i}}+\beta\left(\mathrm{R}_{\mathrm{mt}}-\mathrm{R}_{\mathrm{if}}\right)+\mathrm{u}_{\mathrm{it}}$, each stock beta can be calculated and the table presents the results calculated. Table 2, 4, 6 , and 8 shows the grouping results, along with average excess returns, betas estimation, residual variance and $\mathrm{R}$ square data. Descriptive statistic data for average return and beta are presented in table $3,5,7$, and 9 . 
Table 1: Average excess return and beta

\begin{tabular}{|c|c|c|c|c|}
\hline \multicolumn{5}{|c|}{ For period 2007-2015(Whole Period) } \\
\hline Company & $\begin{array}{l}\text { Average } \\
\text { excess return }\end{array}$ & $\begin{array}{l}\text { Beta } \\
\text { estima- } \\
\text { tion }\end{array}$ & $\begin{array}{l}\text { Residual } \\
\text { variance }\end{array}$ & $\begin{array}{l}\text { R- } \\
\text { squar } \\
\text { e }\end{array}$ \\
\hline $\begin{array}{l}\text { 1. Ammb Holdings } \\
\text { Bhd }\end{array}$ & -0.0257 & 1.1083 & 0.0023 & $\begin{array}{l}0.441 \\
4\end{array}$ \\
\hline $\begin{array}{l}\text { 2. Axiata Group } \\
\text { Berhad }\end{array}$ & -0.0328 & 1.2241 & 0.0045 & $\begin{array}{l}0.334 \\
6\end{array}$ \\
\hline $\begin{array}{l}\text { 3. British American } \\
\text { Tobacco }(\mathrm{M})\end{array}$ & -0.0345 & 0.3141 & 0.0019 & $\begin{array}{l}0.072 \\
7\end{array}$ \\
\hline $\begin{array}{l}\text { 4. Cimb Group } \\
\text { Holdings Berhad }\end{array}$ & -0.0367 & 1.5249 & 0.0035 & $\begin{array}{l}0.497 \\
9\end{array}$ \\
\hline 5. Gamuda Berhad & -0.0284 & 1.7686 & 0.0141 & $\begin{array}{l}0.250 \\
6\end{array}$ \\
\hline 6. Genting Bhd & -0.0298 & 1.3027 & 0.0028 & $\begin{array}{l}0.480 \\
8\end{array}$ \\
\hline $\begin{array}{l}\text { 7. Genting Malaysia } \\
\text { Berhad }\end{array}$ & -0.0450 & 0.7973 & 0.0022 & $\begin{array}{l}0.306 \\
1\end{array}$ \\
\hline $\begin{array}{l}\text { 8. Hap Seng Consol- } \\
\text { idated Bhd }\end{array}$ & -0.0279 & 1.1990 & 0.0098 & $\begin{array}{l}0.180 \\
6\end{array}$ \\
\hline $\begin{array}{l}\text { 9. Hong Leong Bank } \\
\text { Bhd }\end{array}$ & -0.0482 & 0.6673 & 0.0016 & $\begin{array}{l}0.294 \\
9\end{array}$ \\
\hline $\begin{array}{l}\text { 10. Hong Leong } \\
\text { Financial Group }\end{array}$ & -0.0274 & 0.8671 & 0.0023 & $\begin{array}{l}0.330 \\
4\end{array}$ \\
\hline $\begin{array}{l}\text { 11. IOI Corporation } \\
\text { Bhd }\end{array}$ & -0.0352 & 1.4332 & 0.0037 & $\begin{array}{l}0.454 \\
6\end{array}$ \\
\hline $\begin{array}{l}\text { 12. Kuala Lumpur } \\
\text { Kepong Bhd }\end{array}$ & -0.0379 & 1.0996 & 0.0037 & $\begin{array}{l}0.328 \\
0\end{array}$ \\
\hline $\begin{array}{l}\text { 13. Malayan Bank- } \\
\text { ing Bhd }\end{array}$ & -0.0326 & 0.9453 & 0.0023 & $\begin{array}{l}0.371 \\
7 \\
\end{array}$ \\
\hline $\begin{array}{l}\text { 14. Nestle (Malay- } \\
\text { sia) Berhad }\end{array}$ & 0.0037 & 0.2652 & 0.0013 & $\begin{array}{l}0.075 \\
5\end{array}$ \\
\hline $\begin{array}{l}\text { 15. Petronas Da- } \\
\text { gangan Bhd }\end{array}$ & -0.0170 & 0.5244 & 0.0036 & $\begin{array}{l}0.104 \\
3\end{array}$ \\
\hline $\begin{array}{l}\text { 16. Petronas Gas } \\
\text { Bhd }\end{array}$ & -0.0255 & 0.3952 & 0.0014 & $\begin{array}{l}0.144 \\
3 \\
\end{array}$ \\
\hline 17. Ppb Group Bhd & -0.0274 & 1.0010 & 0.0032 & $\begin{array}{l}0.317 \\
6\end{array}$ \\
\hline 18. Public Bank Bhd & -0.0269 & 0.9451 & 0.0010 & $\begin{array}{l}0.569 \\
6\end{array}$ \\
\hline $\begin{array}{l}\text { 19. Rhb Bank Ber- } \\
\text { had }\end{array}$ & -0.0272 & 1.3320 & 0.0032 & $\begin{array}{l}0.452 \\
4\end{array}$ \\
\hline 20. Sime Darby Bhd & -0.0321 & 1.1720 & 0.0015 & $\begin{array}{l}0.578 \\
8\end{array}$ \\
\hline $\begin{array}{l}\text { 21. Telekom Malay- } \\
\text { sia Bhd }\end{array}$ & -0.0297 & 0.4266 & 0.0071 & $\begin{array}{l}0.037 \\
0\end{array}$ \\
\hline 22. UMW Holding & -0.0502 & 0.7987 & 0.0025 & $\begin{array}{l}0.278 \\
8\end{array}$ \\
\hline $\begin{array}{l}\text { 23. Ytl Corporation } \\
\text { Bhd }\end{array}$ & -0.0214 & 0.6135 & 0.0031 & $\begin{array}{l}0.153 \\
7 \\
\end{array}$ \\
\hline $\begin{array}{l}\text { 24. Ytl Power Inter- } \\
\text { national Bhd }\end{array}$ & -0.0351 & 0.5422 & 0.0020 & $\begin{array}{l}0.182 \\
0 \\
\end{array}$ \\
\hline
\end{tabular}

Time series for testing period 2007-2015

\section{Estimation of SML}

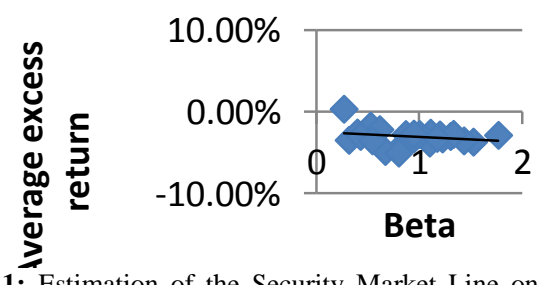

averag excess return

Fig. 1: Estimation of the Security Market Line on Malaysia Stock Exchange. Testing period 2007-2015

From the table 2 above, it expresses the results of whole period for the study. It is ranging from January 2007 to December 2015.

CAPM claims that the only elements to explain return difference among stocks is beta. This clarifies that higher beta is always associated with higher stock return and lower beta is related to lower stock return. The result depicts that the lowest beta is not always associated with lowest return. This can be seen from stock 14 (Nestle Malaysia Berhad). Stock 14 has the lowest beta but it has the highest return. For stock 22 (UMW Holding), the lowest return $(-0.0502)$ also is linked to a relative high beta (0.7987). This means the relation between beta and return is flatter than CAPM prediction and return difference cannot be explained by beta.

The results of all positive $\mathrm{R}^{2}$ value imply a significant linearity in this model. The $\mathrm{R}^{2}$ results lie between stock $21(0.0037)$ and stock $20(0.5788) . R^{2}$ value is low which indicates the ineffectiveness of beta coefficient to the measure of market risk. $\mathrm{R}^{2}$ shows that the market premium (independent variable) can explained the $57.88 \%$ of variation for stock $20,56.96 \%$ of variation for stock 18 , and $49.79 \%$ of variation for stock 4 and so on.

This study investigates the risk and return relationship in Malaysia stock market using the CAPM framework. As mentioned earlier, all the hypothesis and assumptions have to be verified in order for the CAPM to be valid. The findings of the study are presented below:

Table 1: Summary of result

\begin{tabular}{|l|l|l|l|l|l|}
\hline \multicolumn{7}{|c|}{} & $\begin{array}{l}\text { Whole } \\
\text { Period }\end{array}$ & $\begin{array}{l}\text { Period } \\
\mathbf{1}\end{array}$ & $\begin{array}{l}\text { Period } \\
\mathbf{2}\end{array}$ & $\begin{array}{l}\text { Period } \\
\mathbf{3}\end{array}$ \\
\hline Null hypothesis 1: SML & Support & Support & Support & Reject \\
\hline $\begin{array}{l}\text { Null hypothesis 2: Non- } \\
\text { Linearity }\end{array}$ & Support & Support & Support & Support \\
\hline $\begin{array}{l}\text { Null hypothesis 3: Non- } \\
\text { systematic risks }\end{array}$ & Support & Support & Support & Support \\
\hline
\end{tabular}

Empirical Test for whole period (2007-2015)

Table 2: SML for testing period 2007-2015

\begin{tabular}{|c|c|c|c|c|}
\hline & Coefficient & Value & T-value & P-value \\
\hline $\begin{array}{l}\text { Estimation } \\
\text { of SML }\end{array}$ & $\gamma_{0}$ & -0.024484233 & -4.461992019 & 0.000195174 \\
\hline & $\gamma_{1}$ & -0.006428501 & -1.182167805 & 0.249759377 \\
\hline
\end{tabular}

The results of SML for whole period are presented in table 10 . The coefficient of $\gamma_{0}$ is -0.024484233 with a $\mathrm{P}$ value of 0.000195174 indicate that $\gamma_{0}$ is significant different from zero since that $\mathrm{P}$ value is smaller than 0.05 . Regarding $\mathrm{T}$ - test, the value of -4.461992019 is fallen outside the range of 2.069 and also shows the result $\gamma_{0}$ is significantly different from zero. There is no consistent with CAPM assumption.

Further from table 10, the coefficient of $\gamma_{1}$ is -0.006428501 with a $P$ value of 0.249759377 illustrated that $\gamma_{1}$ is not significant larger than zero. The T test of slope $\gamma_{1}$ accepts the null hypothesis as the T-value $(-1.182167805)$ is within the brackets of 2.069 , which means that $\gamma_{1}$ is not significantly different from zero. CAPM assumes $\gamma_{1}$ must be greater than zero, so the result of CAPM is being rejected and is inconsistent with CAPM hypothesis. Null hypothesis 1 is not being rejected.

Since R-square is very low and this implies that there is not a clear relationship between beta and excess returns(57).

Table 3: Non-linearity for testing period 2007-2015

\begin{tabular}{|l|l|l|l|l|}
\hline & Coefficient & Value & T-value & P-value \\
\hline $\begin{array}{l}\text { Non- } \\
\text { linearity }\end{array}$ & $\gamma_{0}$ & -0.008462185 & -0.817829682 & 0.422637258 \\
\hline & $\gamma_{1}$ & -0.047438729 & -2.024435683 & 0.055829643 \\
\hline & $\gamma_{2}$ & 0.021632873 & 1.794541596 & 0.087136698 \\
\hline $\begin{array}{l}\text { R- } \\
\text { square }\end{array}$ & $18.475 \%$ & \multicolumn{4}{|l}{} \\
\cline { 1 - 3 } & \multicolumn{4}{|l}{}
\end{tabular}

The results of the estimated values for non-linearity are presented in the table 11. Results indicated that $\gamma_{2}$ is 0.021632873 with a $P$ value of 0.087136698 . Since $P$ value is larger than alpha value of 0.05 , this presents that the $\gamma_{2}$ is not significant different from zero. $\mathrm{T}$ value 1.794541596 is less than 2.069 at 5 per cent of significant level indicate that $\gamma_{2}$ is significantly equal to zero. Null hypothesis 
is accepted and it is consistent with CAPM assumption that relationship between beta and expected rate of return is linear.

Table 4: Non-systematic risk for testing period 2007-2015

\begin{tabular}{|c|c|c|c|c|}
\hline & Coefficient & Value & T-value & P-value \\
\hline $\begin{array}{l}\text { Non- } \\
\text { systematic } \\
\text { risks }\end{array}$ & $\gamma_{0}$ & $\begin{array}{l}- \\
0.007645565\end{array}$ & $\begin{array}{l}- \\
0.629719521\end{array}$ & 0.536006 \\
\hline & $\gamma_{1}$ & $\begin{array}{l}- \\
0.048963294\end{array}$ & $\begin{array}{l}- \\
1.852818928\end{array}$ & 0.078724 \\
\hline & $\gamma_{2}$ & 0.02268365 & 1.56325791 & 0.133677 \\
\hline & $\gamma_{3}$ & $\begin{array}{l}- \\
0.133731891\end{array}$ & $\begin{array}{l}-137837463 \\
0.13\end{array}$ & 0.891747 \\
\hline R-square & $18.552 \%$ & & & \\
\hline
\end{tabular}

Table 12 illustrates the result of non-systematic risk effect on the stock return. Value of $\gamma_{3}$ is -0.133731891 with a $\mathrm{P}$ value of 0.891747 . P-value is larger than alpha value 0.05 , which means $\gamma 3$ is statistically equal to zero. $\mathrm{T}$ value of $\gamma_{3}$ is equivalent to 0.137837463 which is within the range of 2.069. Therefore, null hypothesis 3 is accepted. The result is consistent to CAPM assumption that non-systematic risk can be diversified away. Therefore, the foundation theory of CAPM is not fully accepted in whole period since ex post SML is not being supported.

\subsection{Whole Period: Security Market Line}

For the Security Market Line, null hypothesis 1 is accepted in the whole period; it indicates the result is contradicted to the Capital Asset Pricing Model.

Based on the Capital Asset Pricing Model theory, beta is only the element that can used to give explanation to the securities return differences. However, this research shows the result that is contradicted with the CAPM theory. Positive relationship between beta and expected stock return in Malaysia stock market does not have a strong evidence to support it.

Empirical analysis of this research oppose against the earlier researchers' work such as (41). Many researches such as (58-61) also showed a positive relationship between beta and expected stock return is being contradicted in this research.

Higher risk does not associate with higher of return is supported with the (62). When looking at the side for emerging countries, most of the study shows a contradict results for the Capital Asset Pricing Model. Based on the (63), it proved that beta and stock return do not seem to be related in emerging countries. (31) also proved that positive relationship between beta and return was not significant. There was a weak relationship between beta and return in Taiwan and South Korea also being indicated by (64).

For the period 1995 to 2006 in Malaysia, the test showed insignificant result for the relationship between beta and expected return (65). In Malaysia, the result also showed that it does not support for the Capital Asset Pricing Model theory that indicated that higher systematic risk will come along will higher return(66). This research finding is consistent with some of the early empirical test. According to the result in this research, there is no strong evidence to show that higher systematic risk can gain higher return in Malaysia Stock Market. The relation between beta and return is flatter than the prediction of Capital Asset Pricing Model and high beta does not necessary yields high return in Malaysia Stock Exchange Market.

\subsection{Whole Period: Nonlinearity}

In order to examine the nonlinearity relation between beta and return, beta square coefficient is introduced into the model. When null hypothesis 2 is accepted, Capital Asset Pricing Model definition indicted that there should be a linear relationship between beta and returns is valid. The findings show the linear relation does exist in Malaysia Stock Exchange Market for the period 2007 to 2015. There is an evidence prove that expected rate of return is linearly related to the stock beta in this research.

The findings of this research are supported for the Capita Asset Pricing Model. There are many supportive evidences for previous research. (66) had done research in Malaysia Stock Exchange and the result is consistent with our findings which linear reltionship between beta and return does exist. Some earlier researches such as $(47,67,68)$ also support that beta and stock return has a linear relationship in their research. Expected return-beta relationship is linear also was being proven in the Amman Stock Exchange(49). There was linear relationship arose between beta and return also being indicated by $(46,58)$. Therefore, the findings of this research are line with previous study.

The findings of this research prove that the Capital Asset Pricing Model linear relationship between beta and return is adequate to portray the generating process of return. Beta is able to explain the cross sectional variation in expected rate of returns fully in this linear relationship. The result is consistent with the Capital Asset Pricing Model for nonlinearity.

\subsection{Whole Period: Non-systematic Risk}

According to Capital Asset Pricing Model, unsystematic risk can be diversified away by having a well-diversified portfolio with including the stock from different industries(69).

This research is conducted to examine whether the Capital Asset Pricing Model sufficiently captures all the essential aspects of reality by containing the unsystematic risk and the interaction term of market risk and unsystematic risk of securities. Failure to reject null hypothesis 3 is an indication that unsystematic risk does not have the effect on the return of the assets. The findings prove that residual error which indicate the non market factors such as unsystematic risk/unique risk has no contributes anythings towards the excess return of the assets.

The result is consistent with the Capital Asset Pricing Model assumption. Prior researches such as Yingyan Guo (29) and (30) also proved that unsystematic risk does not have effect for the expected rate of return in their research. The result also is similar to the earlier research such as (31) which proved that residual risk had not influence on expected stock return. The findings is also consistent with the (70) which the results showed return will not be influenced by the unsystematic risk for most of the period.

CAPM hypothesis about the unsystematic risk effect on returns of the stocks, the findings of this research indicate that people are compensated for systematic risk only but not for unsystematic risk Operating activities of the companies will not have effect on returns of stocks during the whole period.

Seeing the results from the whole period ranging from year 2007 to year 2015, Capital Asset Pricing Model is not strongly supported in the Malaysia Stock Exchange Market. The hypothesis of positive relationship between beta and expected rate return does not have a strong evidence to prove it. Therefore, same regression test is applied for the sub period. The purpose is want to find out whether there are any more supportive evidences in the sub period on the CAPM in the Malaysia Stock Market.

\subsection{Sub-Period: Security Market Line}

Regarding to the security market line $\gamma_{1}$ should be equivalent to the average risk premium. Although the result of Security Market Line shows a reject in the whole period, but during sub period three, beta and expected return show a positive relationship and this is consistent with the CAPM prediction. Thereby, positive relationship between beta and return cannot be fully rejected in Malaysia Stock Exchange Market.

This research finding is corresponding to the $(43,71-73)$ that discovered during an up market, risk and return had a positive relation, and during down market, there were no positive relationship between beta and return. "Malaysia's economy is enjoying a gravity-defying boom that is confounding sceptics in year 
2011(74)." show that during sub period 3, Malaysia is an up market. According to The Star Online (2016), it stated that Malaysia global financial crisis happened in year 2008/2009(75). This indicates a market downturn.

However, the result for different sub periods in this study mostly reject the hypothesis that beta and expected return has a positive relationship. Two out of three sub period results clearly reject the beta and expected return positive relation. From the result above, positive relationship between beta and expected return is inconsistent with CAPM and it cannot give conclusion evidence in favour of the CAPM.

The findings of this research are in line with (76) that the research had discovered inconsistent relationship between beta and expected return by using data sets from different periods of sample.

\subsection{Sub-Period: Nonlinearity}

Regarding to the nonlinearity between the relation of beta and expected rate of return, according to the Capital Asset Pricing Model, null hypothesis 2 should be accepted in order to have a linearity relationship between risk and return. As looking into all the sub period, the null hypothesis 2 is accepted and there is a linear relationship between beta and expected return. The findings of this research are line with the Capital Asset Pricing Model assumption.

The findings of this research have many supportive evidences for previous research. In Malaysia Stock Exchange, linear relationship between beta and expected return does exist (66) and the result is consistent with our findings. There was also linear relationship between beta and return also being indicated by $(46,58)$. Therefore, the findings of this research are consistent with previous study.

\subsection{Sub-Period: Unsystematic Risk}

As mentioned above, in order for CAPM to be verified, null hypothesis 3 is being accepted and all residual risk should have no effect to the expected return. The supportive evidence from the entire period test is the explanatory power of unsystematic risk. By looking into all the three sub period, the null hypotheses for all three sub period are accepted and this indicated that the unsystematic risk is not significantly counted for the expected return. This can be indicated that systematic risks sufficiently comprise whole important aspect of the risk. The unsystematic risk such as business risk and operating activities of the companies will not have influences on returns of stocks in Malaysia Stock Exchange.

The findings of this research are in line with the previous study which had been conducted in Malaysia Stock Exchange Market such as (77) that indicated unsystematic risk has not effect on the expected return.

When examining the Capital Asset Pricing Model, the whole nine year does not showed any strong evidence to support the validity of this model as it does not have the strong evidence to support the positive relationship between beta and return. In order to obtain a better estimation, the whole period is divided into 3 sub periods. The results have revealed some better estimates as during sub period 3 ranging from the year 2011 to 2015 , the findings proved that the CAPM is valid during those period. However, it still does not have strong evidence to support the Capital Asset Pricing Model in Malaysia Stock Market as most of the period, the positive relationship between risk and return does not exist.

\section{Conclusion}

In all research paper, there are bounds to be some area for improvement for all the research papers. It goes the same for this study. The recommendations will be as a guideline for future researchers who do a follow up study for this related topic.
First of all, since this research is using a low frequency which is monthly data, future studies can use the high frequency data which is weekly or daily data for a longer period. It can be tried to revalidated findings in the emerging countries including Malaysia.

Secondly, when examine for the Capital Asset Pricing Model, the future study can identify other variables that will affect the variation in expected returns of asset. The future researchers can take into the consideration of following variables which are Earning per Share (EPS), Price to Earning (P/E), Dividend Yield of stock, Market value to Book value ratio, firm size or other related financial and marketing indicators. Many researches had indicated those variables have a significant impact toward the return on the stocks (78-80).

Thirdly, the future study can expand the study period for at least ten years in order to cover more firms and data available. The portfolio beta should be used in the future study instead of the beta from individual companies. Sample size and observation should be increased in order to have a more accurate result. By increasing the observation period, the period can be performed in another way. Relationship between stock return and beta should distinguish from bearish market and bullish market(81). As mentioned by (82), beta and expected return should be positive related during bullish market and vice versa. Thus, the test period can further allocated into two categories which are down market and up market period.

In addition, the validity of other asset pricing models also needs to be tested in future study. Future study should attempt to add in other pricing model into their study such as Arbitrage Pricing Model. It can allow more factors that can affect the rate of return of the securities rather than just using the beta alone.

At this point it is also critical to remember that KLCI is used to be the proxy of market and market portfolio in this research. People must bear in mind that this index is just comprises common stocks only. However, the theory adopts that the market portfolio should contains all the tradable assets such as bonds, options, futures, stocks and even real estate property and human capital. In conclusion, as relying on the empirical findings above and taking into consideration of all the stated assumptions, Capital Asset Pricing Model does not fully support in this empirical study. Therefore, we can conclude that Capital Asset Pricing Model does not fully hold true in Malaysia Stock Exchange Market during period 2007 to 2015 .

\section{References}

[1] Clare AD, Priestley R. Risk factors in the Malaysian stock market. Pacific-Basin Finance Journal. 1998;6(1-2):103-14.

[2] Berdica K. An introduction to road vulnerability: what has been done, is done and should be done. Transport policy. 2002;9(2):11727.

[3] Rackwitz R. Reliability analysis - a review and some perspectives. Structural safety. 2001;23(4):365-95

[4] Chen N-F, Roll R, Ross SA. Economic forces and the stock market. Journal of business. 1986:383-403.

[5] Dempsey M. The capital asset pricing model (CAPM): the history of a failed revolutionary idea in finance? Abacus. 2013;49(S1):723.

[6] Heshmat NA. Analysis of the capital asset pricing model in the Saudi stock market. International Journal of Management. 2012;29(2):504.

[7] Markowitz HM, Todd GP, Sharpe WF. Mean-variance analysis in portfolio choice and capital markets: John Wiley \& Sons; 2000.

[8] Tehranian H, Cornett MM, Marcus AJ, Saunders A. Earnings management, corporate governance, and true financial performance. 2006.

[9] Mitchell M, Pulvino T. Characteristics of risk and return in risk arbitrage. the Journal of Finance. 2001;56(6):2135-75

[10] Goldenberg DH, Robin AJ. THE ARBITRAGE PRICING THEORY AND COST-OF-CAPITAL ESTIMATION: THE CASE OF ELECTRIC UTILITIES. Journal of Financial Research. 1991;14(3):181-96 
[11] Ross S. Arbitrage, Risk Return in Finance ed. I. Friend and J Bicksler, Cambridge, Mass: Ballinger. 1976.

[12] Stambaugh RF. Arbitrage pricing with information. Journal of Financial Economics. 1983;12(3):357-69.

[13] CHEN NF. Some empirical tests of the theory of arbitrage pricing. The Journal of Finance. 1983;38(5):1393-414.

[14] Chamberlain G. Funds, factors, and diversification in arbitrage pricing models. Econometrica: Journal of the Econometric Society. 1983:1305-23.

[15] Ross S, Westerfield R, Jordan B. Fundamentals of Corporate Finance. McGrawHill. Google Scholar. 2013.

[16] Van Horne J. Fundamentals of Financial Management/James C Van Horne, John M. Wachowicz, Jr.-.-Harlow (England). London, New York: Prentice Hall Inc., Financial Times; 2008.

[17] Brigham EF, Houston JF. Fundamentals of financial management: Cengage Learning; 2012

[18] Bodie Z, Kane A, Marcus AJ. Ready Notes to Accompany Essentials of Investments: McGraw-Hill Europe; 2005.

[19] Drehmann M, Sorensen S, Stringa M. The integrated impact of credit and interest rate risk on banks: an economic value and capita adequacy perspective. 2008 .

[20] Lajeri F, Dermine J. Unexpected inflation and bank stock returns: The case of France 1977-1991. Journal of Banking \& Finance. 1999;23(6):939-53.

[21] Flannery MJ, Hameed AS, Harjes RH. Asset pricing, time-varying risk premia and interest rate risk. Journal of Banking \& Finance. 1997;21(3):315-35.

[22] Lloyd WP, Shick RA. A test of Stone's two-index model of returns Journal of Financial and Quantitative Analysis. 1977;12(3):363-76.

[23] Fisher R. The Genetical Theory of Natural Selection Oxford University Press Oxford Google Scholar. 1930.

[24] Uwubanmwen A, Eghosa IL. Inflation Rate and Stock Returns Evidence from the Nigerian Stock Market. International Journal of Business and Social Science. 2015;6(11):155-67.

[25] Adler M, Dumas B. Exposure to currency risk: definition and measurement. Financial management. 1984:41-50.

[26] Hussain N, Khan AQ. An Analysis of the Stock Return and Exchange Rate Variation on Market Return of Pharmaceutical Industry in Pakistan. World Applied Sciences Journal. 2014;31(6):1180-7.

[27] Michailidis G, Tsopoglou S, Papanastasiou D. Testing the capital asset pricing model (CAPM): The case of the emerging Greek securities market. 2006.

[28] Li X, Miffre J, Brooks C, O’Sullivan N. Momentum profits and time-varying unsystematic risk. Journal of Banking \& Finance. 2008;32(4):541-58.

[29] Yuanjun Z, Zengrui T. Research on evaluation of venture capital fund project based on data envelopment analysis model. Journal of Computational and Theoretical Nanoscience. 2016;13(2):1266-74

[30] Hasan MZ, Kamil AA, Mustafa A, Baten MA. Relationship between risk and expected returns: Evidence from the dhaka stock exchange. Procedia Economics and Finance. 2012;2:1-8.

[31] Olakojo S, Ajide K. Testing the Capital Asset Pricing Model (CAPM): The Case of the Nigerian Securities Market. International Business Management. 2010;4(4):239-42.

[32] Damodaran A. Investment valuation, 2. Aufl, New York. 2002;817.

[33] Fama EF, French KR. The cross-section of expected stock returns. the Journal of Finance. 1992;47(2):427-65.

[34] Amihud Y, Christensen BJ, Mendelson H. Further evidence on the risk-return relationship: Graduate School of Business, Stanford University; 1992.

[35] Kothari SP, Shanken J, Sloan RG. Another look at the cross-section of expected stock returns. The journal of finance. 1995;50(1):185224.

[36] Chan LK, Lakonishok J. Robust measurement of beta risk. Journal of financial and quantitative analysis. 1992;27(2):265-82.

[37] Salman F. Risk-Return-Volume relationship in an Emerging Stock Market. Applied Economics Letters 9. 2002:549-52.

[38] Omet G, Khasawneh M, Khasawneh J. Efficiency Tests and Volatility Effects: Evidence from the Jordanian Stock Market. Applied Economics Letters 9(12). 2002:817-21.

[39] Li X, Miffre J, Brooks C, O’Sullivan N. Momentum profits and time-varying unsystematic risk. Journal of Banking and Finance. 2008;32:541-58

[40] Chui A, Titman S, Wei J. Individualism and momentum around the world. Journal of Finance. 2010;65:361-92.

[41] Fama EF, MacBeth JD. Risk, return, and equilibrium: Empirical tests. Journal of political economy. 1973;81(3):607-36
[42] Sharpe WF, Cooper GM. Risk-return classes of New York stock exchange common stocks, 1931-1967. Financial Analysts Journal. 1972;28(2):46-54.

[43] Basher SA, Sadorsky P. Oil price risk and emerging stock markets. Global finance journal. 2006;17(2):224-51.

[44] Banz RW. The Relationship Between Return and Market Value ofCommon Stock. Journal of Finance Economics 9:1. 1981:3-18.

[45] Gibbons MR. Multivariate Tests of Financial Models: A new Approach. Journal of Financial Economics 10:1. 1982:3-27.

[46] Stambaugh RF. On the Exclusion of Assets from Tests from the Two Parameter Model: A sensitivity Analysis. Journal of Financial Economic 10:3. 1982:237-68

[47] Bilgin R, Basti E. Further Evidence on the Validity of CAPM: the Istanbul Stock Exchange Application. Inzinerine EkonomikaEngineering Economics. 2014;25(1):5-12.

[48] Salman F. Risk-return-volume relationship in an emerging stock market. Applied Economics Letters. 2002;9(8):549-52.

[49] Alqisie A. Validity of Capital Assets Pricing Model (CAPM) (Empirical Evidences from Amman Stock Exchange). Journal of Management Research. 2016;8(1).

[50] Ball R, Brown P, Officer R. Asset Pricing in the Australian Industrial Equity Market. Australian Journal of Management, 1(1) 1976:1-32.

[51] Fama E, French k. Multi-factor explanations of asset pricing anomalies. Journal of Finance. 1996;51:55-84.

[52] Theriou N, Aggelidis V, Maditinos D, Sevic Z. 1.(2010). Testing the relation between beta and returns in the Athens stock exchange. Managerial Finance.36(12):1043-56.

[53] Gürsoy CT, Rejepova G. Test of capital asset pricing model in Turkey. 2007.

[54] Groenewold N. FORECASTING BETA: HOW WELL DOES THE 'FIVE-YEAR RULE OF THUMB' DO? 1999.

[55] Elton EJ, Gruber MJ, Brown SJ, Goetzmann WN. Modern portfolio theory and investment analysis: John Wiley \& Sons; 2009.

[56] Bodie Z, Kane A, Marcus AJ. Investments: McGraw-Hill; 2009.

[57] Czekierda B. The Capital Asset Pricing Model: Test of the model on the Warsaw Stock Exchange. Institutionen för Ekonomi,Statistik och Informatik. 1976:1-57.

[58] Reinganum MR. Misspecification of capital asset pricing: Empirical anomalies based on earnings' yields and market values. Journal of financial Economics. 1981;9(1):19-46.

[59] Banz RW. The relationship between return and market value of common stocks. Journal of financial economics. 1981;9(1):3-18.

[60] Gibbons MR. Multivariate tests of financial models: A new approach. Journal of financial economics. 1982;10(1):3-27.

[61] Lau ST, Lee CT, McInish TH. Stock returns and beta, firms size, $\mathrm{E} / \mathrm{P}, \mathrm{CF} / \mathrm{P}$, book-to-market, and sales growth: evidence from Singapore and Malaysia. Journal of multinational financial management. 2002;12(3):207-22.

[62] Alqisie A, Alqurran T. Validity of Capital Assets Pricing Model (CAPM)(Empirical Evidences from Amman Stock Exchange). Journal of Management Research. 2016;8(1):207-23.

[63] Estrada J. The cost of equity in emerging markets: a downside risk approach. 2000.

[64] Cheung Y-L, Wong K-A, Ho Y-K. The pricing of risky assets in two emerging Asian markets-Korea and Taiwan. Applied Financial Economics. 1993;3(4):315-24.

[65] Isa M, Hassan A, Puah C-H, Yong Y-K. Risk and return nexus in Malaysian stock market: Empirical evidence from CAPM. 2008

[66] Lee HS, Cheng FF, Chong SC. Markowitz Portfolio Theory and Capital Asset Pricing Model for Kuala Lumpur Stock Exchange: A Case Revisited. International Journal of Economics and Financial Issues. 2016;6(S3) 59-65.

[67] Kolani P, Vikpossi AE. An Analysis of the Relationship between Risk and Expected Return inthe BRVM Stock Exchange: Test of the CAPM. Published by Sciedu Press; 2014.

[68] Ball R, Brown P, Officer R. Asset pricing in the Australian industrial equity market. Australian Journal of Management. 1976;1(1):1-32.

[69] Michailidis G, Tsopoglou S, Papanastasiou D, Mariola E. Testing the capitalasset pricing model (capm): the case of the emerging Greek securities market. International Research Journal of Finance and Economics. 2006;4:78-91.

[70] Pamane K, Vikpossi AE. An analysis of the relationship between risk and expected return in the BRVM stock exchange: test of the CAPM. Research in World Economy. 2014;5(1):13.

[71] Isakov D. Is beta still alive? Conclusive evidence from the Swiss stock market. The European Journal of Finance. 1999;5(3):202-12. 
[72] Tang GY, Shum WC. The relationships between unsystematic risk, skewness and stock returns during up and down markets. International Business Review. 2003;12(5):523-41.

[73] Fletcher GP. Rethinking criminal law: Oxford University Press; 2000.

[74] Malaysia's Economy. Sarawak Score [Internet]. 2016. Available from: $\quad$ http://www.recoda.com.my/inside-sarawak/malaysiaseconomyl.

[75] Ng F. Malaysia's looming economic woes. TheStar Online [Internet]. 2016 May 14. Available from: http://www.thestar.com.my/business/businessnews/2016/05/14/malaysias-looming-economic-woes/.

[76] Hasan M, Kamil AA, Mustafa A, Baten MA. A validity test of capital asset pricing model for Dhaka stock exchange. Journal of Applied Sciences. 2011;11(20):3490-6.

[77] Lee H-S, Ng DC-Y, Lau T-C, Ng C-H. Forecasting Stock Market Volatility on Bursa Malaysia Plantation Index. International Journal of Finance and Accounting. 2016;5(1):54-61.

[78] Arslan M, Zaman R. Impact of Dividend Yield and Price Earnings Ratio on Stock Returns: A Study Non-Financial listed Firms of Pakistan. Research Journal of Finance and Accounting. 2014;5(9):68-74

[79] Al-Mwall M, Ahmed AM, A.Fayssal. The Relationship between P/E Ratio, Dividend Yield Ratio,Size and Stock Returns in Jordanian Companies: A Co-integration Approach. International Research Journal of Finance and Economics. 2010;49(7):87-103.

[80] Raymond YC. Price-Earnings Ratios, Dividend Yields and Rea Estate Stock Prices. Journal of Real Estate Portfolio Management. 2002;8(2):107-13.

[81] Pettengill GN, Sundaram S, Mathur I. The Conditional Relation between Beta and Returns. Journal of Financial and Quantitative Analysis. 1995;30:101-16.

[82] Andersen TG, Bollerslev T, Diebold FX, Wu G. Realized beta: Persistence and predictability. Econometric Analysis of Financia and Economic Time Series: Emerald Group Publishing Limited; 2006. p. 1-39. 